\title{
A phase 1 multiple-dose study of orteronel in Japanese patients with castration-resistant prostate cancer
}

\author{
Kazuhiro Suzuki $\cdot$ Seiichiro Ozono $\cdot$ Akito Yamaguchi $\cdot$ Hidekazu Koike $\cdot$ \\ Hiroshi Matsui $\cdot$ Masao Nagata $\cdot$ Takatoshi Takubo $\cdot$ Kana Miyashita $\cdot$ \\ Takafumi Matsushima $\cdot$ Hideyuki Akaza
}

Received: 6 November 2014 / Accepted: 14 December 2014 / Published online: 24 December 2014

(c) The Author(s) 2014. This article is published with open access at Springerlink.com

\begin{abstract}
Purpose Orteronel (TAK-700) is a non-steroidal, selective, reversible inhibitor of 17,20-lyase. We evaluated the safety, tolerability, pharmacokinetics, pharmacodynamics, and antitumor effect of orteronel with or without prednisolone in Japanese patients with castration-resistant prostate cancer (CRPC).

Methods We conducted a phase 1 study in men with progressive and chemotherapy-naïve CRPC. Patients received orteronel orally at doses of 200-400 mg twice daily (BID) with or without oral prednisolone (5 mg BID). Dose-limiting toxicity (DLT) was assessed during Cycle 1 (28 days). Patients could continue study treatment until any of criteria for treatment discontinuation were met. Gonadotropinreleasing hormone therapy was continued in patients without prior orchidectomy.

Results Fifteen patients were enrolled and administered at least one dose of orteronel. No DLTs were reported during
\end{abstract}

K. Suzuki $(\bowtie) \cdot$ H. Koike $\cdot$ H. Matsui

Department of Urology, Gunma University Graduate School

of Medicine, Gunma, Japan

e-mail:kazu@gunma-u.ac.jp

S. Ozono $\cdot$ M. Nagata

Department of Urology, Hamamatsu University School

of Medicine, Shizuoka, Japan

A. Yamaguchi

Harasanshin Hospital, Fukuoka, Japan

T. Takubo $\cdot$ K. Miyashita $\cdot$ T. Matsushima

Takeda Pharmaceutical Company Limited, Osaka, Japan

H. Akaza

Department of Strategic Investigation on Comprehensive Cancer

Network, Research Center for Advanced Science and Technology,

The University of Tokyo, Tokyo, Japan
Cycle 1 in this study. Adverse events (AEs) were reported in all 15 patients. Most common AEs ( $>30 \%$ ) were hyperlipasemia (47\%), hyperamylasemia (40\%), and constipation (33\%). Acute pancreatitis (Grades 2 and 3) and pancreatitis (Grade 1) were complicated in three patients during the study. Dose-dependent increase in plasma orteronel concentrations was indicated over the $200-400 \mathrm{mg}$ BID dose range. Prednisolone coadministered did not alter PK of orteronel. Serum testosterone was rapidly suppressed below the lower limit of quantification across all doses. Of 15 subjects, 13 achieved at least a $50 \%$ reduction from baseline in prostate-specific antigen.

Conclusions Orteronel at doses up to $400 \mathrm{mg}$ BID was tolerable in Japanese CRPC patients. The present results support further evaluation of orteronel with or without prednisolone.

Keywords Orteronel - Castration-resistant prostate cancer $\cdot$ 17,20-Lyase inhibitor $\cdot$ Phase 1

\section{Introduction}

Prostate cancer is the second most common cancer in men worldwide [1]. In Japan, the number of patients with prostate cancer is rapidly increasing because of the aging of the population, westernization of dietary habits, and advances in diagnostic techniques. The incidence of the malignancy is estimated at 15.1 per 100,000 patients (age-standardized rate) [1].

Castration by orchidectomy or treatment with agonists of receptors for gonadotropin-releasing hormone $(\mathrm{GnRH})$, also known as luteinizing hormone-releasing hormone (LH-RH), has been the standard of care in advanced prostate cancer. Patients with prostate cancer that has recurred 
after local therapy or has distantly disseminated usually respond to androgen deprivation therapy (ADT); however, most patients eventually experience disease progression within a median of 18-24 months [2].

The intra-prostatic synthesis of testosterone from adrenal-derived precursors likely accounts for the relatively high testosterone levels in the prostate after ADT [3] and castration-resistant prostate cancer (CRPC) cells express all necessary enzymes for the de novo synthesis of dihydrotestosterone [4]. CYP17A1 is a key enzyme in the generation of androgens and estrogens in the adrenal glands and tumor tissue, and it catalyzes two independently regulated steroid reactions, involving $17 \alpha$-hydroxylase and 17,20-lyase in the biosynthesis pathway [5]. This finding led to the concept of CYP17A1 inhibition for depleting both intra-tumoral and extragonadal sources of steroid ligands [5-9]. The importance of this pathway in CRPC has been supported by positive results in phase 3 trials with abiraterone acetate (Zytiga $\left.^{\circledR}\right)[10,11]$. However, toxicities attributed to a syndrome of secondary mineralocorticoid excess have been observed with abiraterone, and coadministration of a mineralocorticoid receptor antagonist or glucocorticoid is required to suppress adrenocorticotropic hormone (ACTH) levels [12].

Orteronel (TAK-700) is a non-steroidal, selective, reversible inhibitor of 17,20-lyase. It inhibited 17,20lyase activity 5.4-fold more potently than it suppressed 17-hydroxylase activity in cell-free enzyme assays, suggesting that orteronel treatment results in the inhibition of androgen synthesis with only partial inhibition of $17 \alpha$-hydroxylase activity, which allows adrenal cortisol synthesis to continue. Preclinical studies revealed that orteronel reduced serum androgen levels in vivo in monkeys [13]. By selectively inhibiting the extragonadal synthesis of androgens in either the adrenal cortex or prostate tumor cells, orteronel may represent a new therapeutic option for patients with CRPC. The relative selectivity of orteronel for 17,20-lyase may also offer benefits compared with other therapies that target androgen synthesis accompanied by decreased requirements for concurrent administration of steroids such as prednisolone.

This is the first clinical report to evaluate the safety, tolerability, pharmacokinetics (PK), pharmacodynamics (PD), and efficacy of orteronel based on the findings of a phase 1 study in Japanese patients with chemotherapy-naïve CRPC.

\section{Patients and methods}

\section{Patients}

Patients were recruited from three centers in Japan. The study was conducted in accordance with the Declaration of Helsinki/Good Clinical Practices. The Institutional Review Board approved all aspects of the study, and all participants provided written informed consent. The eligibility criteria included histologically or cytologically confirmed prostate adenocarcinoma, prostate-specific antigen (PSA) levels of $\geq 2 \mathrm{ng} / \mathrm{mL}$ at screening, an increase from nadir in PSA levels in $\geq 2$ successive measurements by the time of screening, well-controlled castration (serum testosterone level $<0.5 \mathrm{ng} / \mathrm{mL}$ ), an Eastern Cooperative Oncology Group (ECOG) performance status of $0-2$ at screening, and adequate liver, renal, and bone marrow functions. Patients were also required to discontinue all antiandrogen therapy for at least 6 (bicalutamide) or 4 weeks (any other therapy) before the first dose of orteronel. Patients with an unacceptable cardiac complication were excluded. Patients who had received prior chemotherapy for prostate cancer were also excluded. Eligibility did not require a determination of the presence or absence of metastasis.

\section{Study design}

This was a phase 1 , open-label, multiple-dose study in Japanese patients with chemotherapy-naïve, hormone therapy-resistant prostate cancer (also known as CRPC). For patients who had not undergone prior orchidectomy, the castrated testosterone level was maintained by $\mathrm{GnRH}$ therapy. The primary objective of this study was to assess the safety, tolerability, and PK of orteronel as a single agent or in combination with prednisolone in patients with CRPC. The secondary objective was to determine the PD and antitumor effect of orteronel using serum PSA levels, PSA response rates, and objective disease response rates in patients with CRPC [14].

Patients received orteronel orally either with or without oral prednisolone at the following doses: $200 \mathrm{mg}$ twice daily (200-mg BID cohort), 400 mg BID (400-mg BID cohort), or $400 \mathrm{mg}$ BID plus prednisolone $5 \mathrm{mg}$ BID (400mg BID plus prednisolone cohort). The propriety of transitions to subsequent dose cohort was judged on the basis of the number of patients with dose-limiting toxicities (DLTs) during Cycle 1 (28 days). Furthermore, additional two cohorts in which subjects received orteronel $300 \mathrm{mg}$ BID (300-mg BID cohort) or orteronel $300 \mathrm{mg}$ BID plus prednisolone $5 \mathrm{mg}$ BID (300-mg BID plus prednisolone cohort) were assessed on the basis of a preliminary interim analysis. Patients could continue study treatment until criteria for treatment discontinuation were met. The use of aldosterone antagonists (e.g., eplerenone) was allowed for patients with clinical symptoms of mineralocorticoid excess such as hypertension, hypokalemia, and edema.

\section{Assessments}

Safety assessments included the evaluation of adverse events (AEs), laboratory profiles, physical examination, and vital 
Table 1 Demographic and other baseline characteristics

\begin{tabular}{|c|c|}
\hline & $\begin{array}{l}\text { Orteronel } \\
\text { All subjects }(N=15)\end{array}$ \\
\hline \multicolumn{2}{|l|}{$\operatorname{Sex}-n(\%)$} \\
\hline Male & $15(100)$ \\
\hline \multicolumn{2}{|l|}{ Age-years } \\
\hline$n$ & 15 \\
\hline Mean (SD) & $69.5(4.90)$ \\
\hline Median & 71.0 \\
\hline Min, $\max$ & 60,77 \\
\hline \multicolumn{2}{|c|}{$\begin{array}{l}\text { Gleason classification score at the time of the latest examination- } \\
n(\%)\end{array}$} \\
\hline$\leq 6$ & $0(0)$ \\
\hline 7 & $1(7)$ \\
\hline 8 & $4(27)$ \\
\hline 9 & $7(47)$ \\
\hline 10 & $3(20)$ \\
\hline \multicolumn{2}{|l|}{ Histological type- $n(\%)$} \\
\hline Adenocarcinoma & $14(93)$ \\
\hline Well differentiated & $0(0)$ \\
\hline Moderately differentiated & $3(20)$ \\
\hline Poorly differentiated & $10(67)$ \\
\hline Unclassified & $1(7)$ \\
\hline Other & $1(7)$ \\
\hline \multicolumn{2}{|l|}{ TNM classification- $n(\%)$} \\
\hline T3N0M0 & $2(13)$ \\
\hline T3N0M1 & $2(13)$ \\
\hline T3N1M0 & $2(13)$ \\
\hline T3N1M1 & $2(13)$ \\
\hline T3N1MX & $1(7)$ \\
\hline T4N0M1 & $2(13)$ \\
\hline T4N1M1 & $3(20)$ \\
\hline TXN0M1 & $1(7)$ \\
\hline \multicolumn{2}{|c|}{$\begin{array}{l}\text { Eastern cooperative oncology group (ECOG) performance status- } \\
n(\%)\end{array}$} \\
\hline 0 & $15(100)$ \\
\hline 1 or 2 & $0(0)$ \\
\hline
\end{tabular}

signs throughout the study. AEs were graded using National Cancer Institute Common Terminology Criteria for Adverse Events (NCI-CTCAE) v3.0. Analysis of serum amylase and lipase was added to the clinical laboratory tests before enrollment of patients into the 400-mg BID plus prednisolone cohort because pancreatitis was reported during the study. A safety follow-up was performed for 28 days after the final dose of the study treatment. During Cycle 1 (28 days), DLT was also evaluated. DLTs were defined as any drug-related AE of $\geq$ Grade 3 and pre-specified cardiac-related AEs of lower grade. Hypertension, hypokalemia, and edema attributed to increased ACTH secretion maintained at Grade 2 or lower through the use of eplerenone were not considered DLTs.
The pharmacokinetic endpoints were to evaluate PK profiles in plasma and urinary excretion of unchanged orteronel and a primary metabolite (M-I). Unchanged orteronel and M-I in plasma and urine were determined by the validated high-performance liquid chromatography-tandem mass spectrometry.

Endocrine parameters such as serum testosterone and dehydroepiandrosterone sulfate (DHEA-S) were measured for PD analysis. The blood sample were collected on Days $1,8,15$, and 22 of Cycle 1 and then on Day 1 of each subsequent 28 -day cycle. Assay procedure for testosterone was improved during the study, and the lower limit of quantification (LLOQ) for testosterone changed from 0.05 to $0.03 \mathrm{ng} / \mathrm{mL}$.

The efficacy endpoints were serum PSA levels, PSA response rates based on the Prostate Cancer Clinical Trials Working Group (PCWG) 2 criteria, and objective disease response rates based on the General Rule for Clinical and Pathological Studies on Prostate Cancer and modified RECIST version 1.0. PSA levels were measured on Days 1 and 15 in Cycle 1, on Day 1 of Cycle 2 and each subsequent cycle. Tumor assessments were performed on Day 29,85 , and every 12 -week cycle for subsequent cycles.

Statistical analysis

Three patients (a maximum of six patients) were to be included in each cohort. The number of patients was determined according to the "Guidelines on clinical evaluation method of antineoplastics" in Japan (PFSB/ELD, 2005) [15], and the setting was not based on the statistical rationale. Standard summary statistics were used for safety, PK, $\mathrm{PD}$, and efficacy analyses.

\section{Results \\ Patients and exposure}

Between April 2010 and January 2012, 15 patients (3 in each cohort) were enrolled in this study. All 15 patients received at least one dose of orteronel. At the time of analysis, 13 patients had discontinued orteronel treatment because of the following reasons: lack of efficacy in eight patients and TEAEs in five patients. The remaining two patients were under treatment: One patient in the 200-mg BID cohort and one patient in the 400-mg BID plus prednisolone cohort whose current dose of orteronel was reduced to $200 \mathrm{mg}$ BID with prednisolone $5 \mathrm{mg}$ BID.

Demographic and other baseline characteristics are shown in Table 1 . The overall median age was 71.0 years. All 15 patients experienced relapses and had a baseline ECOG performance status of 0 . Gleason scores at the time 
Table 2 Exposure to orteronel

\begin{tabular}{|c|c|c|c|c|c|c|}
\hline & \multicolumn{6}{|l|}{ Orteronel } \\
\hline & $200 \mathrm{mg}(N=3)$ & $300 \mathrm{mg}(N=3)$ & $\begin{array}{l}300 \mathrm{mg}+ \\
\text { prednisolone } \\
(N=3)\end{array}$ & $400 \mathrm{mg}(N=3)$ & $\begin{array}{l}400 \mathrm{mg}+ \\
\text { prednisolone } \\
(N=3)\end{array}$ & $\begin{array}{l}\text { All subjects } \\
(N=15)\end{array}$ \\
\hline \multicolumn{7}{|c|}{ Treatment days (days) } \\
\hline$n$ & 3 & 3 & 3 & 3 & 3 & 15 \\
\hline Mean (SD) & $597.0(307.44)$ & $342.7(129.07)$ & $172.3(92.32)$ & $61.0(24.52)$ & $397.3(311.21)$ & $314.1(260.51)$ \\
\hline Median & 420.0 & 399.0 & 142.0 & 60.0 & 499.0 & 276.0 \\
\hline Min, $\max$ & 419,952 & 195,434 & 99,276 & 37,86 & 48,645 & 37,952 \\
\hline \multicolumn{7}{|c|}{ Total amount of doses taken $\left(10^{3} \mathrm{mg}\right)$} \\
\hline$n$ & 3 & 3 & 3 & 3 & 3 & 15 \\
\hline Mean (SD) & $227.4(133.89)$ & $171.5(63.49)$ & 86.9 (49.69) & $36.7(8.93)$ & $156.1(131.92)$ & $135.7(103.74)$ \\
\hline Median & 167.4 & 156.2 & 82.5 & 35.0 & 133.0 & 133.0 \\
\hline Min, $\max$ & 134,381 & 117,241 & 40,139 & 29,46 & 37,298 & 29,381 \\
\hline \multicolumn{7}{|c|}{ Relative dose intensity in cycle $1(\%)$} \\
\hline$n$ & 3 & 3 & 3 & 3 & 3 & 15 \\
\hline Mean (SD) & $100.00(0.000)$ & $100.00(0.000)$ & $99.80(0.344)$ & $95.24(8.248)$ & $100.00(0.000)$ & $99.01(3.681)$ \\
\hline Median & 100.00 & 100.00 & 100.00 & 100.00 & 100.00 & 100.00 \\
\hline Min, $\max$ & $100.0,100.0$ & $100.0,100.0$ & $99.4,100.0$ & $85.7,100.0$ & $100.0,100.0$ & $85.7,100.0$ \\
\hline \multicolumn{7}{|c|}{ Relative dose intensity ${ }^{\mathrm{a}}$ during study (\%) } \\
\hline$n$ & 3 & 3 & 3 & 3 & 3 & 15 \\
\hline Mean (SD) & $93.21(11.650)$ & $85.96(18.311)$ & $82.34(15.212)$ & $79.22(15.894)$ & $65.77(36.373)$ & $81.30(20.331)$ \\
\hline Median & 99.88 & 92.63 & 83.70 & 72.92 & 74.65 & 83.70 \\
\hline Min, $\max$ & $79.8,100.0$ & $65.2,100.0$ & $66.5,96.8$ & $67.4,97.3$ & $25.8,96.9$ & $25.8,100.0$ \\
\hline
\end{tabular}

${ }^{\text {a }}$ Relative dose intensity $=($ total dose received/total dose expected per initial dose $) \times 100$

of the latest examination were 7 or more for all patients. All patients received prior medication for prostate cancer, and two patients $(13 \%)$ received other prior therapies for prostate cancer including radiation to prostate gland in one patient and palliative radiation to lumbar vertebrae metastasis and bilateral orchidectomy in one patient.

The median duration of treatment days across the cohorts was 276.0 days, and the treatment duration was shorter in the 400-mg BID cohort (60.0 days) than in the other cohorts (Table 2). All 15 patients completed Cycle 1 treatment at the prescribed dose and were eligible for DLT assessment.

Safety results

The treatment-emergent AEs (TEAEs) that occurred in $\geq 10 \%$ of patients during the study are shown in Table 3 . Neither DLTs nor serious AEs (SAEs) were reported in Cycle 1 in any cohort. Overall, all 15 patients (100\%) experienced at least 1 TEAE, and 14 patients (93\%) experienced at least 1 treatment-related AE. Most common TEAEs that were observed in $>30 \%$ of patients were hyperlipasemia, hyperamylasemia, and constipation.
No deaths were reported in this study. Nine patients (60\%) experienced a total of 14 SAEs, of which nine were considered to be related to the study treatment. No treatment-related SAE was observed in the 200- and 300-mg BID cohorts. Acute pancreatitis was reported in two patients (400-mg BID cohort and 400-mg BID plus prednisolone cohort) and resulted in permanently discontinuation of orteronel. Other treatment-related SAEs reported in one patient each were diabetes mellitus, gastric ulcer hemorrhage, hyperamylasemia, hyperlipasemia, interstitial lung disease, pneumonitis, and pyrexia. We had two experiences of the elevation of pancreatic enzymes in 400-mg BID cohort. First one was observed on Day 60. The patient had complaint of continuous abdominal discomfort. Laboratory data of amylase and lipase were elevated. Slight peripancreatic effusion was pointed out by abdominal CT scan. The signs and symptom were diagnosed as acute pancreatitis. After discontinuation of orteronel, the symptom and abnormal data were resolved. Second one was asymptomatic and checked in some laboratory data including amylase and lipase as monitoring. The patient had Grade 3 hyperamylasemia and Grade 4 hyperlipasemia with unremarkable pancreatic change by CT scan. Afterward, we added the periodical monitoring of 
Table 3 Subject incidence of treatment-emergent adverse events by preferred term in descending order of frequency ( $\geq 10 \%$ subjects in all subjects during the study, any Grade and Grade 3 or higher)

\begin{tabular}{|c|c|c|c|c|c|c|c|c|c|c|c|c|}
\hline \multirow{3}{*}{$\begin{array}{l}\text { Preferred } \\
\text { term }\end{array}$} & \multicolumn{12}{|c|}{ TAK-700 (orteronel) } \\
\hline & \multicolumn{2}{|c|}{$\begin{array}{l}200 \mathrm{mg}(N=3) n \\
(\%)\end{array}$} & \multicolumn{2}{|c|}{$\begin{array}{l}300 \mathrm{mg}(N=3) n \\
(\%)\end{array}$} & \multicolumn{2}{|c|}{$\begin{array}{l}300 \mathrm{mg}+\text { predniso- } \\
\text { lone }(N=3) n(\%)\end{array}$} & \multicolumn{2}{|c|}{$\begin{array}{l}400 \mathrm{mg}(N=3) n \\
(\%)\end{array}$} & \multicolumn{2}{|c|}{$\begin{array}{l}400 \mathrm{mg}+\text { predniso- } \\
\text { lone }(N=3) n(\%)\end{array}$} & \multicolumn{2}{|c|}{$\begin{array}{l}\text { All subjects } \\
(N=15) n(\%)\end{array}$} \\
\hline & $\begin{array}{l}\text { Any } \\
\text { grade }\end{array}$ & $\begin{array}{l}\text { Grade } 3 \\
\text { or higher }\end{array}$ & $\begin{array}{l}\text { Any } \\
\text { grade }\end{array}$ & $\begin{array}{l}\text { Grade } 3 \\
\text { or higher }\end{array}$ & $\begin{array}{l}\text { Any } \\
\text { grade }\end{array}$ & $\begin{array}{l}\text { Grade } 3 \\
\text { or higher }\end{array}$ & $\begin{array}{l}\text { Any } \\
\text { grade }\end{array}$ & $\begin{array}{l}\text { Grade } 3 \\
\text { or higher }\end{array}$ & $\begin{array}{l}\text { Any } \\
\text { grade }\end{array}$ & $\begin{array}{l}\text { Grade } 3 \\
\text { or higher }\end{array}$ & $\begin{array}{l}\text { Any } \\
\text { grade }\end{array}$ & $\begin{array}{l}\text { Grade } 3 \\
\text { or higher }\end{array}$ \\
\hline \multicolumn{13}{|c|}{ Any adverse event } \\
\hline $\begin{array}{c}\text { Number of } \\
\text { subjects }\end{array}$ & $3(100)$ & $1(33)$ & $3(100)$ & $3(100)$ & $3(100)$ & $3(100)$ & $3(100)$ & $2(67)$ & $3(100)$ & $3(100)$ & $15(100)$ & $12(80)$ \\
\hline $\begin{array}{l}\text { Hyperlipa- } \\
\text { semia }\end{array}$ & - & - & $3(100)$ & $3(100)$ & $3(100)$ & $2(67)$ & $1(33)$ & $1(33)$ & - & - & $7(47)$ & $6(40)$ \\
\hline $\begin{array}{l}\text { Hyperamyla- } \\
\text { semia }\end{array}$ & - & - & $2(67)$ & $1(33)$ & $3(100)$ & $1(33)$ & $1(33)$ & $1(33)$ & - & - & $6(40)$ & $3(20)$ \\
\hline Constipation & - & - & - & - & $2(67)$ & - & - & - & $3(100)$ & - & $5(33)$ & - \\
\hline Dysgeusia & - & - & - & - & $1(33)$ & - & $3(100)$ & - & - & - & $4(27)$ & - \\
\hline $\begin{array}{l}\text { Hepatic } \\
\text { function } \\
\text { abnormal }\end{array}$ & $1(33)$ & - & $1(33)$ & - & - & - & $1(33)$ & - & $1(33)$ & - & $4(27)$ & - \\
\hline Hypertension & $1(33)$ & - & $1(33)$ & $1(33)$ & - & - & $2(67)$ & - & - & - & $4(27)$ & $1(7)$ \\
\hline Malaise & - & - & - & - & $1(33)$ & - & $2(67)$ & - & $1(33)$ & - & $4(27)$ & - \\
\hline Hypokalemia & - & - & - & - & - & - & $3(100)$ & $1(33)$ & - & - & $3(20)$ & $1(7)$ \\
\hline $\begin{array}{l}\text { Nasopharyn- } \\
\text { gitis }\end{array}$ & $1(33)$ & - & - & - & - & - & - & - & $2(67)$ & - & $3(20)$ & - \\
\hline Nausea & - & - & $1(33)$ & - & - & - & $1(33)$ & - & $1(33)$ & - & $3(20)$ & - \\
\hline Rash & - & - & - & - & - & - & - & - & $3(100)$ & - & $3(20)$ & - \\
\hline $\begin{array}{l}\text { Abdominal } \\
\text { pain upper }\end{array}$ & - & - & - & - & - & - & $1(33)$ & - & $1(33)$ & - & $2(13)$ & - \\
\hline $\begin{array}{l}\text { Blood creatine } \\
\text { phospho- } \\
\text { kinase } \\
\text { increased }\end{array}$ & 1 (33) & - & - & - & $1(33)$ & - & - & - & - & - & $2(13)$ & - \\
\hline Contusion & - & - & - & - & - & - & $1(33)$ & - & $1(33)$ & - & $2(13)$ & - \\
\hline $\begin{array}{l}\text { Diabetes mel- } \\
\text { litus }\end{array}$ & - & - & - & - & $1(33)$ & $1(33)$ & - & - & $1(33)$ & - & $2(13)$ & $1(7)$ \\
\hline Fall & - & - & - & - & - & - & - & - & $2(67)$ & - & $2(13)$ & - \\
\hline Insomnia & $1(33)$ & - & - & - & - & - & - & - & $1(33)$ & - & $2(13)$ & - \\
\hline $\begin{array}{l}\text { Pancreatitis } \\
\text { acute }\end{array}$ & - & - & - & - & - & - & $1(33)$ & - & $1(33)$ & $1(33)$ & $2(13)$ & $1(7)$ \\
\hline Pneumonia & - & - & - & - & $1(33)$ & - & - & - & $1(33)$ & $1(33)$ & $2(13)$ & $1(7)$ \\
\hline Vomiting & - & - & - & - & - & - & $1(33)$ & - & $1(33)$ & - & $2(13)$ & - \\
\hline
\end{tabular}

Adverse events were coded using the MedDRA version 13.0

A subject counts once for each preferred term

pancreatic enzymes in this protocol after these events. The onset of abnormal pancreatic enzymes was reported during early treatment phase (around Cycle 2 or Cycle 3 ). In most patients, these abnormal elevations were reported without any symptom or radiographic abnormalities in pancreas. Three conditions were diagnosed as acute pancreatitis or pancreatitis in this study. Other two pancreatitis were also reported in 400-mg BID cohort with or without prednisolone (Grades 1 and 2). In 300-mg BID orteronel with or without prednisolone cohorts, pancreatitis was not reported. A total of ten patients experienced pancreatic-related AEs. Two patients were recovered from the abnormality without any dose change of orteronel. Other three patients were rechallenged with orteronel after the pancreatic enzyme returned to normal. Of these three patients, two continued treatment without any experience of pancreas-related TEAEs. Another patient experienced a re-elevation of pancreatic enzyme, but pancreatitis was not complicated.

Mineralocorticoid-related TEAEs such as hypertension $(n=4)$ and hypokalemia $(n=3)$ were mild, and the 
symptoms were manageable without dose reduction or dose hold of orteronel except for one Grade 3 hypokalemia. All patients who experienced these events were enrolled in prednisolone-free cohort. No TEAE associated with adrenal insufficiency was reported in this study.

No Grade 3 or higher abnormalities were observed in hematologic test or urinalysis. No clinically significant abnormal 12-lead ECG and echocardiography findings were observed either in any patient or at any assessment point during the study.

\section{PK results}

The maximum plasma concentration $\left(C_{\max }\right)$ of orteronel was observed at approximately 1-3 $\mathrm{h}$ after the morning dose on Day 8 of Cycle 1 in all cohorts (Table 4). The plasma concentrations of orteronel increased with the BID dosing in all cohorts and the cumulative ratios of area under the plasma concentration-time curve (AUC) on Day 8 ranged from 1.10 to 1.67 . Dose-dependent increases in $C_{\max }$ and AUC of orteronel on Day 8 were indicated in the dose range of the 200 and $400 \mathrm{mg}$ BID. Differences in the values of PK parameters between prednisolone-free and prednisolone coadministration were not clearly observed at orteronel doses of 300 and $400 \mathrm{mg}$ BID. The time to achieve $C_{\max }\left(T_{\max }\right)$ of M-I on Day 8 was approximately $3-8 \mathrm{~h}$ in all cohorts. AUC of M-I on Day 8 was approximately $30-50 \%$ of that of orteronel in each cohort. The fractional urinary excretion rates for $24 \mathrm{~h}$ after the morning dose on Day 15 ranged from 36 to $47 \%$ of the dose for orteronel and from 14 to $21 \%$ of the dose for M-I, indicating that more than half of the oral dose was excreted into urine in all cohorts.

\section{PD and antitumor effects}

The endocrine parameters are presented in Table 5. Serum testosterone was suppressed to LLOQ or lower by 1 week after the initiation of orteronel treatment (Day 8) across all cohorts. Serum DHEA-S was also suppressed by orteronel on Day 8. The mean level of serum DHEA-S on Day 8 was lower in $400 \mathrm{mg}$ BID of orteronel than lower dose of orteronel. In addition, the levels in prednisolone-coadministration cohorts were lower than those in corresponding prednisolone-free cohorts.

The overall median maximum PSA reduction was $88.48 \%$ during the study. Of 15 PSA-evaluable patients, 13 (87\%) achieved at least a $50 \%$ reduction from baseline in PSA. With regard to objective disease responses based on the General Rule for Clinical and Pathological Studies on Prostate Cancer, no patient had a best response of complete response (CR) and five patients had a best response of partial response (PR). The objective response rate $(\mathrm{CR}+\mathrm{PR})$ was $33 \%$ (5/15 patients). Regarding objective disease responses based on modified RECIST version 1.0, only six patients had measurable disease. No patient had a best response of CR or PR.

\section{Discussion}

A total of 15 patients were treated by orteronel at doses of 200, 300, $300 \mathrm{mg}$ BID plus prednisolone, 400, and $400 \mathrm{mg}$ BID plus prednisolone. Orteronel was well tolerated at doses up to $400 \mathrm{mg}$ BID in Japanese CRPC patients either as a single agent or in combination with prednisolone. No DLTs were reported during the DLT assessment period in any cohort. PSA responses and testosterone levels indicated the potential clinical efficacy of orteronel with or without prednisolone coadministration.

The small amount of remaining androgens after castration for prostate cancer plays an important role in the proliferation of prostate tumor cells. Abiraterone was developed as an androgen production inhibitor [11]. To prevent mineralocorticoid excess syndrome and adrenal insufficiency, prednisolone is required to coadminister with abiraterone. Orteronel selectively inhibits 17,20-lyase and may offer benefits compared with other therapies that target androgen synthesis, with a reduced need for concurrent administration of steroids (prednisolone). In contrast, high dose of orteronel may block 17-hydroxylase activity, thereby resulting in increased mineralocorticoid activity in patients not receiving concomitant glucocorticoids. Thus, mineralocorticoid excess syndrome (hypertension and hypokalemia) and adrenal insufficiency-related TEAEs were assessed as significant AEs in this study.

Consequently, as mineralocorticoid excess syndromerelated TEAEs, hypertension, and hypokalemia were reported. Both events were observed in the prednisolonefree cohorts, and most patients who experienced these events received high dose (400 mg BID) of orteronel. These patients except one did not require dose reduction or dose hold, and their symptoms were manageable by treatment with eplerenone and other agents. No adrenal insufficiency-related TEAEs were reported in any cohorts. These results suggest that concomitant administration of prednisolone (5 mg BID) may not be required for preventing mineralocorticoid excess syndrome-related TEAEs, especially in lower doses of orteronel (200 or $300 \mathrm{mg}$ BID). Pancreatic enzyme abnormalities were observed with relatively high frequencies. Such changes were asymptomatic in most patients, who did not display the evidence of pancreatitis in diagnostic imaging. In the study, increases in pancreatic enzyme levels were intensively reported in Cycles 2 and 3 , and these abnormalities subsequently returned to normal without dose change or after dose discontinuation 
Table 4 Pharmacokinetic parameters of orteronel and M-I on Day 8 of Cycle 1

\begin{tabular}{|c|c|c|c|c|c|}
\hline \multirow[t]{2}{*}{ PK parameter } & \multicolumn{5}{|l|}{ Cohort } \\
\hline & $200 \mathrm{mg}$ BID & $300 \mathrm{mg}$ BID & $300 \mathrm{mg}+$ pred BID & $400 \mathrm{mg}$ BID & $400 \mathrm{mg}+$ pred BID \\
\hline \multicolumn{6}{|l|}{ Orteronel } \\
\hline$T_{\max }$ & $1.00(1.00,2.92)$ & $3.00(2.00,7.75)$ & $3.00(2.00,5.00)$ & $2.97(2.95,2.98)$ & $2.00(1.08,3.00)$ \\
\hline$C_{\max }(\mu \mathrm{g} / \mathrm{mL})$ & $1.58(0.38)$ & $3.10(1.0)$ & $3.19(0.42)$ & $4.70(1.3)$ & $5.96(2.1)$ \\
\hline $\mathrm{AUC}_{0-8 \mathrm{~h}}(\mathrm{~h} \mu \mathrm{g} / \mathrm{mL})$ & $7.64(2.1)$ & $14.5(4.5)$ & $16.7(1.4)$ & $28.6(11)$ & $30.7(11)$ \\
\hline $\mathrm{R}(\mathrm{AUC})$ & $1.58(0.62)$ & $1.10(0.17)$ & $1.67(0.33)$ & $1.46(0.42)$ & $1.66(0.13)$ \\
\hline \multicolumn{6}{|l|}{ M-I } \\
\hline$T_{\max }$ & $2.92(2.00,5.00)$ & $7.75(5.00,8.00)$ & $4.98(3.00,5.00)$ & $4.83(2.98,4.93)$ & $3.00(2.75,5.00)$ \\
\hline$C_{\max }(\mu \mathrm{g} / \mathrm{mL})$ & $0.478(0.25)$ & $0.885(0.27)$ & $1.25(0.21)$ & $1.37(0.37)$ & $1.47(0.67)$ \\
\hline $\mathrm{AUC}_{0-8 \mathrm{~h}}(\mathrm{~h} \mu \mathrm{g} / \mathrm{mL})$ & $3.17(1.5)$ & $5.29(1.2)$ & $7.97(2.0)$ & $9.02(1.6)$ & $9.83(4.2)$ \\
\hline
\end{tabular}

$n=3$, median (min, max) for $T_{\max }$, mean (SD) for other parameters

$\mathrm{AUC}_{0-8 \mathrm{~h}}$ : area under the plasma concentration-time curve from 0 to $8 \mathrm{~h}$ post-dose, $C_{\text {max }}$ : maximum plasma concentration, pred: $5 \mathrm{mg}$ prednisolone, $\mathrm{R}(\mathrm{AUC}): \mathrm{AUC}_{0-8 \mathrm{~h}}[$ Day 8$] / \mathrm{AUC}_{0-8 \mathrm{~h}}\left[\right.$ Day 1], $T_{\max }$ : time to $C_{\max }$

Table 5 Summary statistics of endocrine panel

\begin{tabular}{|c|c|c|c|c|c|c|}
\hline \multirow[t]{2}{*}{ Assessment (unit) visit } & & \multicolumn{5}{|l|}{ Orteronel } \\
\hline & & $200 \mathrm{mg}(N=3)$ & $300 \mathrm{mg}(N=3)$ & $\begin{array}{l}300 \mathrm{mg}+\text { prednisolone } \\
(N=3)\end{array}$ & $400 \mathrm{mg}(N=3)$ & $\begin{array}{l}400 \mathrm{mg}+\text { prednisolone } \\
(N=3)\end{array}$ \\
\hline \multicolumn{7}{|l|}{ Testosterone (ng/mL) } \\
\hline Screening & Mean (SD) & $0.153(0.0611)$ & $0.123(0.0702)$ & $0.127(0.0473)$ & $0.057(0.0115)$ & $0.053(0.0058)$ \\
\hline Cycle 1 Day 8 & Mean (SD) & $0.050(0.0000)$ & $0.030(0.0000)$ & $0.030(0.0000)$ & $0.050(0.0000)$ & $0.043(0.0115)$ \\
\hline Cycle 2 Day 1 & Mean (SD) & $0.050(0.0000)$ & $0.030(0.0000)$ & $0.030(0.0000)$ & $0.050(0.0000)$ & $0.037(0.0115)$ \\
\hline \multicolumn{7}{|l|}{ DHEA-S $(\mu \mathrm{g} / \mathrm{dL})$} \\
\hline Screening & Mean (SD) & $114.7(8.96)$ & $146.7(79.83)$ & $136.0(52.68)$ & $60.3(8.50)$ & $40.3(7.57)$ \\
\hline Cycle 1 Day 8 & Mean (SD) & $25.0(7.21)$ & $23.3(14.57)$ & $6.3(4.16)$ & $9.3(0.58)$ & $2.3(0.58)$ \\
\hline Cycle 2 Day 1 & Mean (SD) & $30.0(9.64)$ & $24.3(11.93)$ & $2.3(0.58)$ & $19.3(16.29)$ & $2.0(0.00)$ \\
\hline
\end{tabular}

The lower limits of quantification (LLOQ) are: testosterone 0.05 and $0.03 \mathrm{ng} / \mathrm{dL}$, DHEA-S $2.0 \mu \mathrm{g} / \mathrm{dL}$. Testosterone assay was changed during the study, making LLOQ changed from 0.05 to $0.03 \mathrm{ng} / \mathrm{mL}$

A cycle was defined as a 4-week (28-day) period

$D H E A-S$ dehydroepiandrosterone sulfate

of orteronel. Although some patients resumed orteronel after recovering from the abnormality, no one complicated acute pancreatitis by rechallenge of orteronel. The patients who received orteronel for a long period did not exhibit an abnormal pancreatic enzyme in the late treatment phase (Day 150 or later), suggesting that increases in pancreatic enzyme levels occurred in the early treatment phase of orteronel, and that the possibility of delayed and/or recurrent increases is relatively low. In the case of asymptomatic elevation of pancreatic enzymes, the abnormalities were reversible by dose hold of orteronel, and the orteronel treatment could be resumed with or without dose reduction. Although the mechanism(s) of the increases in pancreatic enzymes is unclear, it is possible that orteronel causes drug-induced pancreatic hyperenzymemia rather than pancreatitis similarly as other drugs such as sorafenib [16]. We need to further discuss the relationship between increase in pancreatic enzyme and in pancreatitis.

$T_{\max }$ of orteronel was approximately 1-3 $\mathrm{h}$ after oral administration, and more than half of the oral dose was excreted into urine in all cohorts. M-I was considered to be a primary metabolite of orteronel, judging from the AUC ratio of M-I to orteronel and the urinary excretion rate of M-I. These findings indicated that orteronel is well absorbed after oral administration, and absorbed orteronel is primarily metabolized into M-I as well as urinary excretion. The comparison of the values of PK parameters between prednisolone-free and prednisolone coadministration suggested no remarkable effect of coadministered prednisolone $(5 \mathrm{mg}$ ) on the PK of orteronel.

Serum testosterone was rapidly suppressed to the LLOQ or lower across all cohorts, suggesting the expected 
pharmacological effects by orteronel in Japanese CRPC patients. Serum DHEA-S, which is the upstream hormone of testosterone synthesis, was also suppressed by orteronel administration. The reduction in serum DHEA-S levels appeared to depend on the orteronel dosage or concurrent administration of prednisolone. However, because of the sensitivity of hormone assays and degree of variability among patients, no significant differences were found in endocrine responses between the 300- and 400-mg BID orteronel. Due to the small number of patients in this study, it may require further evaluation to determine whether 300- or 400-mg BID orteronel is recommended for Japanese CRPC patients.

Mean and median reductions in PSA were evaluated during the study. However, the number of patients was too small to draw meaningful conclusions regarding the dose. The compliance of 2 PSA non-responders to orteronel dosing was sufficient during the study according to their relative dose intensities (96.8 and $83.7 \%$, respectively), and their serum testosterone and DHEA-S concentrations were suppressed to the LLOQ or lower. It has been reported that a certain type of prostate cancer cells grows in a testosterone-independent manner [17], and thus, the 2 PSA non-responders may have developed a testosterone-independent type of prostate cancer.

In conclusion, orteronel at doses up to $400 \mathrm{mg}$ BID was tolerable in Japanese CRPC patients. The results of the present study support further evaluation of orteronel with or without prednisolone.

Acknowledgments The authors would like to thank all patients and their families as well as all investigators and site staff involved in the study. Takeda Bio Development Center Ltd. (currently Takeda Pharmaceutical Company Limited) sponsored this study, provided the study design, and performed statistical analyses. Yutaka Takahashi, SunFlare Co., Ltd., Tokyo, Japan, provided writing and editorial support, funded by Takeda Pharmaceutical Company Limited.

Open Access This article is distributed under the terms of the Creative Commons Attribution License which permits any use, distribution, and reproduction in any medium, provided the original author(s) and the source are credited.

\section{References}

1. Center MM, Jemal A, Lortet-Tieulent J, Ward E, Ferlay J, Brawley O, Bray F (2012) International variation in prostate cancer incidence and mortality rates. Eur Urol 61:1079-1092

2. Hotte SJ, Saad F (2010) Current management of castrate-resistant prostate cancer. Curr Oncol 17(suppl 2):S72-S79

3. Cai C, Balk SP (2011) Intratumoral androgen biosynthesis in prostate cancer pathogenesis and response to therapy. Endocr Relat Cancer 18:R175-R182

4. Locke JA, Guns ES, Lubik AA, Adomat HH, Hendy SC, Wood CA, Ettinger SL, Gleave ME, Nelson CC (2008) Androgen levels increase by intratumoral de novo steroidogenesis during progression of castration-resistant prostate cancer. Cancer Res 68:6407-6415

5. Ang JE, Olmos D, de Bono JS (2009) CYP17 blockade by abiraterone: further evidence for frequent continued hormone-dependence in castration-resistant prostate cancer. Br J Cancer 100:671-675

6. Schweizer MT, Antonarakis ES (2012) Abiraterone and other novel androgen-directed strategies for the treatment of prostate cancer: a new era of hormonal therapies is born. Ther Adv Urol 4:167-178

7. Kaku T, Hitaka T, Ojida A, Matsunaga N, Adachi M, Tanaka T, Hara T, Yamaoka M, Kusaka M, Okuda T, Asahi S, Furuya S, Tasaka A (2011) Discovery of orteronel (TAK-700), a naphthylmethylimidazole derivative, as a highly selective 17,20-lyase inhibitor with potential utility in the treatment of prostate cancer. Bioorg Med Chem 19:6383-6399

8. Payne AH, Hales DB (2004) Overview of steroidogenic enzymes in the pathway from cholesterol to active steroid hormones. Endocr Rev 25:947-970

9. Vasaitis TS, Bruno RD, Njar VC (2011) CYP17 inhibitors for prostate cancer therapy. J Steroid Biochem Mol Biol 125:23-31

10. de Bono JS, Logothetis CJ, Molina A, Fizazi K, North S, Chu L, Chi KN, Jones RJ, Goodman OB Jr, Saad F, Staffurth JN, Mainwaring P, Harland S, Flaig TW, Hutson TE, Cheng T, Patterson H, Hainsworth JD, Ryan CJ, Sternberg CN, Ellard SL, Fléchon A, Saleh M, Scholz M, Efstathiou E, Zivi A, Bianchini D, Loriot Y, Chieffo N, Kheoh T, Haqq CM, Scher HI, COU-AA-301 Investigators (2011) Abiraterone and increased survival in metastatic prostate cancer. N Engl J Med 364:1995-2005

11. Ryan CJ, Smith MR, de Bono JS, Molina A, Logothetis CJ, de Souza P, Fizazi K, Mainwaring P, Piulats JM, Ng S, Carles J, Mulders PF, Basch E, Small EJ, Saad F, Schrijvers D, Van Poppel H, Mukherjee SD, Suttmann H, Gerritsen WR, Flaig TW, George DJ, Yu EY, Efstathiou E, Pantuck A, Winquist E, Higano CS, Taplin ME, Park Y, Kheoh T, Griffin T, Scher HI, Rathkopf DE, COU-AA-302 Investigators (2013) Abiraterone in metastatic prostate cancer without previous chemotherapy. N Engl J Med 368:138-148

12. Attard G, Reid AHM, A'Hern R, Parker C, Oommen NB, Folkerd E, Messiou C, Molife LR, Maier G, Thompson E, Olmos D, Sinha R, Lee G, Dowsett M, Kaye SB, Dearnaley D, Kheoh T, Molina A, de Bono JS (2009) Selective inhibition of CYP17 with abiraterone acetate is highly active in the treatment of castrationresistant prostate cancer. J Clin Oncol 27:3742-3748

13. Yamaoka M, Hara T, Hitaka T, Kaku T, Takeuchi T, Takahashi J, Asahi S, Miki H, Tasaka A, Kusaka M (2012) Orteronel (TAK700), a novel non-steroidal 17,20-lyase inhibitor: effects on steroid synthesis in human and monkey adrenal cells and serum steroid levels in cynomolgus monkeys. J Steroid Biochem Mol Biol 129:115-128

14. Scher HI, Halabi S, Tannock I, Morris M, Sternberg CN, Carducci MA, Eisenberger MA, Higano C, Bubley GJ, Dreicer R, Petrylak D, Kantoff P, Basch E, Kelly WK, Figg WD, Small EJ, Beer TM, Wilding G, Martin A, Hussain M, Prostate Cancer Clinical Trials Working Group (2008) Design and end points of clinical trials for patients with progressive prostate cancer and castrate levels of testosterone: recommendations of the prostate cancer clinical trials working group. J Clin Oncol 26:1148-1159

15. Andoh M, Fujiwara Y, Shimada Y (2006) The revision of guidelines for clinical evaluation methods of anti-cancer drugs in Japan. Gan To Kagaku Ryoho 33:1015-1019 (Article in Japanese; English abstract)

16. Minami H, Kawada K, Ebi H, Kitagawa K, Kim YI, Araki K, Mukai H, Tahara M, Nakajima H, Nakajima K (2008) Phase I and pharmacokinetic study of sorafenib, an oral multikinase inhibitor, in Japanese patients with advanced refractory solid tumors. Cancer Sci 99:1492-1498

17. Pienta KJ, Bradley D (2006) Mechanisms underlying the development of androgen-independent prostate cancer. Clin Cancer Res 12:1665-1671 